\title{
Abhishiktananda: A Christian advaitin
}

\begin{abstract}
Authors:
Celia Kourie ${ }^{1}$

Alex Kurian ${ }^{2,3}$

\section{Affiliations:}

${ }^{1}$ Department of Christian

Spirituality, Church History

and Missiology, University of

South Africa, South Africa

${ }^{2}$ Institute of Formative Spirituality and Counselling, Dharmaram Vidya Kshetram, India

${ }^{3}$ Department of New

Testament Studies,

University of the

Free State, South Africa

Note:

Alex Kurian is a Research Fellow at the University of the Free State, Bloemfontein, South Africa.
\end{abstract}

\section{Correspondence to:}

Celia Kourie

Email:

kouricet@unisa.ac.za

Postal address:

PO Box 392, Unisa 0003

South Africa

Dates:

Received: 31 Mar. 2011

Accepted: 15 June 2011

Published: 25 Oct. 2011

How to cite this article: Kourie, C. \& Kurian, A., 2011, 'Abhishiktananda: A Christian advaitin', HTS Teologiese Studies/ Theological Studies 67(3), Art. \#1054, 8 pages. http:// dx.doi.org/10.4102/hts. v67i3.1054
C 2011. The Authors. Licensee: AOSIS OpenJournals. This work is licensed under the Creative Commons Attribution License.
In our pluralistic society, the diverse religious traditions offer an opportunity for interreligious dialogue which has as its aim an appreciation of, and respect for, the integrity of individual traditions. Swami Abhishiktananda is a clear example of one who offered an alternative to Christian exclusiveness in his willingness to engage in an inter-spiritual lifestyle in which Eastern and Western mystical traditions are seen to be mutually enriching. By opting to make his own life a crucible to test his beliefs and convictions Abhishiktananda endured lifelong trials and tribulations. His life can broadly be divided into four phases, namely the 'fulfilment' phase, with its typical Western triumphalist missionary mentality, followed by the crisis phase thanks to his encounter with Hindu spirituality. This led him to the third phase in which he dared to relativise all conceptualisations as concretisations of the inexpressible Mystery. During the final two years of his life he entered the fourth and the last phase of liberation or 'explosion' of all previous concepts. Abhishiktananda spoke of an experience, which he called ati-Advaita, or Advaitatita which is an experience of Unity and Trinity. He claimed that the sages of India were correct to say neither one nor many, but just to say, nottwo, advaita, and not-one, an-eka.

\section{Introduction}

Thirty-seven years have passed since Abhishiktananda attained his ever cherished Advaita Samadhi (non-dual union) and went on to inspire a generation of Indian Christian theologians. His arrival in India and the path he dared to choose generated powerful currents, waves and ripples in the Indian subcontinent as well as around the world. During the 1960s and 1970s, Bangalore became the epicentre of much theological discussion and experimentation, with the staff members of Dharmaram College, St Peters Seminary and the National Biblical Catechetical and Lirturgical Centre (NBCLC) $)^{1}$ taking daring steps to develop, promote and propagate an Indian Christian theology. However, at present, the state of affairs has changed. Even those movements that followed over the last four decades, such as liberation theology and its subaltern perspective, women's liberation and the Dalit-empowerment movement, are now lacking momentum and vigour. Although various facets of Orientalism emerged in certain quarters, their impact was minimal. Yet, since we are currently celebrating the birth centenary of Abhishiktananda we offer an introduction to the life and thought of Abhishiktananda and its contribution to ongoing religious dialogue in the 21st century.

\section{A brief biography of Abhishiktananda}

Swami Abhishiktananda was born Henri Le Saux on 30 August 1910 at St Briac in Brittany, France. At an early age he felt a vocation to the priesthood and entered the Major Seminary at Rennes in 1926. In 1929, at the age of 19, he wrote to the novice master of the Benedictine Monastery of St Anne de Kergonan seeking admission and was accepted. However, gradually he found that the life in the abbey did not satisfy his desire to experience God. He longed for an even deeper monasticism. By 1934, he realised his life's vocation was to travel to India. It appears that he believed India would help him to lead a life of simplicity and allow a greater degree of renunciation in his monasticism. He began preparing himself by studying Hindu texts, which he believed would help him to communicate effectively with members of the Hindu faith. Despite his desire to go to India, he was not granted permission to make inquiries in this regard until 1945 and he remained in Kergonan Abbey until 1948. Whilst functioning as the abbey's librarian, he had the opportunity to read the works of the Fathers of the Church, in particular those of the Desert and Greek Fathers, from whom he learned the apophatic way of mysticism. Between

1.Dharmaram College is a major study house of the CMI Congregation situated in Bangalore. Dharmaram Vidya Kshetram (DVK) is a Pontifical Athenaeum for higher learning and formation, established by the Congregation for Catholic Education, Vatican, as an independent institute, en OrientalCanon Law, and at Pondicherry in 1778. In 1934, MEP moved the seminary to Bangalore. On 06 January 1976, the Congregation for Catholic Education upgraded the seminary into a faculty under the name of St Peter's Pontifical Institute of Theology. The NBCLC is an all-Indian institution set up in Bangalore to promote and co-ordinate the renewal of Christian life in the Church according to the principles outlined by Vatican II council. 
1946 and 1948, he was placed in charge of teaching novices at the abbey. Prior to this, however, in 1942, Abhishiktananda wrote a manuscript for his mother, entitled Amour et Sagesse [Love and wisdom]. It was a meditation on the Trinity, which he considered the noblest mystery of the faith and in which he refers to God as being beyond thought. As we shall see during the course of this article, the doctrine of the Trinity continued to be important for Abhishiktananda, particularly in his Christian understanding of the advaitic experience.

In 1947, Abhishiktananda wrote to the Bishop of Tiruchirapalli in India, Monsignor Mendonsa, enquiring about the possibility of coming to India. In his letter Abhishiktananda indicated that he sought 'to lead the contemplative life, in the absolute simplicity of early Christian monasticism and at the same time in the closest possible conformity with the traditions of Indian sannyasa' (Stuart [1989] 1995:12). Father Jules Monchanin, who answered his letter on behalf of the Bishop, also shared a similar vision of an Indian Christianity. Abhishiktananda knew Monchanin through his published articles, whilst Monchanin saw Abhishiktananda's desire to come to India as an answer from God and therefore encouraged him to make the journey. Abhishiktananda left France for India in 1948, with the goal of starting a Christian ashram to facilitate a truly Indian Christianity. Together with Monchanin, he founded an ashram on the bank of the Kavery River at Tannirpalli. The ashram was officially called 'Saccidananda Ashram' or 'Eremus Sanctissimae Trinitatis' [Hermitage of the Most Holy Trinity]. But it was more commonly known by the name 'Shantivanam' (Grove of Peace). The ashram was governed by the Benedictine rule, but many Hindu customs were also incorporated, including dressing and acting as Hindu sanyasis. The bishop, Mendonsa, was very supportive of the ashram from its inception. He believed that the approach taken by Monchanin and Abhishiktananda would allow the Indian Church to be as legitimately Indian as possible, just as in previous eras, where the Church was able to articulate the Gospel via Greek and Roman thought and philosophy.

Abhishiktananda's visit to the ashram of Sri Ramana Maharshi ${ }^{2}$ in January 1949 was a turning point in his life. This influence was powerful; it was a:

... call which pierced through everything, rent it in pieces and opened a mighty abyss ... New as these experiences were, their hold on me was already too strong for it ever to be possible for me to disown them.

(Abhishiktananda 1979:9)

From that moment on he tried to move away from the then prevalent Christian attitude and theology of fulfilment and triumphalism, to an appreciation of Hinduism in its own right. He was convinced that the Hindu advaitic experience of the Self was central to any dialogue with Hinduism. He sought to

2.Sri Ramana Maharshi (30 December 1879 - 14 April 1950), considered as great mystic, was born in Tamil Nadu, India. At the age of 16 , he left home for
Arunachala, a mountain at Tiruvannamalai, and lived there for the rest of his life. He Arunachala, a mountain at Tiruvannamalai, and lived there for the rest of his life. He
recommended self-enquiry as the fastest path to liberation. Sri Ramana maintained recommended self-enquiry as the fastest path to liberation. Sri Ramana maintained his presence and quieted the minds of those attuned to it. He gave verbal teachings his presence and quieted the minds of those attuned to it. He gave verbal teachings
only for the benefit of those who could not understand his silence. Though his only for the benefit of those who could not understand his silence. Though his
primary teaching is associated with Advaita Vedanta, he recommended Bhakti to those he saw were fit for it. attain the advaitic experience by accepting Gnanananda Giri ${ }^{3}$ as his Guru. By spending prolonged periods of meditation in the caves of Arunachala in the south of India and at his hermitage at Uttarkashi in the Himalayas, he tried to live what he believed. However, Abhishiktananda had to struggle a great deal to reconcile his advaitic experience with his Christian faith. As he continued his experimental investigation of Advaita, he preferred to use Hindu terminology to express his religious experience and, as such, his beliefs as a Christian transformed (Friesen 1998:31-38). Yet, at times he was afraid that he was exchanging his Christian beliefs and risking his eternal salvation for an illusory experience, a 'mirage' (Panikkar 1998:180). Nevertheless, in his final years, Abhishiktananda became convinced of the authenticity and truth of his advaitic experience. He gradually gave up his dream of a community of Hindu-Christian monks; instead, he devoted himself personally to being a sanyasi who was at the same time both Christian and Hindu. In 1971, looking back on the ashram, Abhishiktananda wrote, 'Expansion in human terms, success, numbers are of no importance. All that belongs to the realm of maya, appearance, and the monk is only concerned with nitya, the real' (Stuart [1989] 1995:108). In 1968, after entrusting Shantivanam to Father Bede Griffiths, an English monk who had joined him in India, he left the ashram to live the life of a hermit in his hermitage at Uttarkashi in the Himalayas, never to return.

Abhishiktananda remained a Roman Catholic priest until his death, even though at times he used to participate in Hindu worship. By way of accepting Marc Chaduc as his disciple, he arranged a joint Hindu-Christian initiation (diksha) led by himself and Swami Chidananda, a Hindu monk at the Sivananda ashram in Rishikesh. It was during his time with his disciple in 1973 that Abhishiktananda received what he regarded as a definitive advaitic experience. The intensity of this experience removed all doubts for him. But it also resulted in a heart attack, which he considered an 'adventure'. He had further advaitic experiences, which, for him, confirmed the validity of his initial experience. After several years of life as a hermit, weakened by the myocardial infarction, he died on 07 December 1973 at Indore nursing home.

According to Raimundo Panikkar, his colleague and confidant, we can discover four stages in the development of Abhishiktananda's life, experience and thought (Baeumer 2000). The first phase could be named the 'fulfilment' phase. He arrived in India with a typical Western triumphalistic missionary mentality. He was ready to bear the 'Whiteman's burden's $^{4}$ of educating, fulfilling, saving and winning the inferior cultures and civilisations for Christ. The second phase was one of crisis, on account of his encounter with Hindu spirituality, personified in Sri Ramana Maharshi, that shook the foundations of his Christian fulfilment theology. Being a Benedictine monk, fortunately, he was open and was ready to listen. The tensions created by his meeting of

3.Swami Gnanananda Giri was born at Managalapuri in Western Karnataka. He had his spiritual apprenticeship in Kashmir and eventually settled in the premises of Arunachala. He died in 1974.

4.See Rudyard Kipling's poem, “The Whiteman's Burden”. 
Hindu spirituality at its highest and purest level were partly theological, partly psychological and partly spiritual. During this stage he was greatly surprised and was torn apart by two experiences, two 'ultimates', two identities, two worlds of religious expression, and, in his own words, 'two loves'. This led him to the third phase, in which he relativised all conceptualisations, particularisations and formulations as 'namarupas' [name and form], which he considered as concretisations of the one, unspeakable, inexpressible Mystery. During the final two years of his life he entered the fourth and last phase of liberation or 'explosion,' of all previous concepts. After experiencing the 'explosion', or 'awakening', which were his own cherished words, we see him redefining and re-identifying the 'correspondences,' which he discovered at both the beginning and the end of his experience. What is fascinating is that the 'explosion' which amounts to a liberation, did not destroy his faith in Jesus, but transformed it.

The name Abhishiktananda can literally mean 'the bliss of the anointed' or 'the anointed bliss', which implies a person 'whose joy is Christ' or 'who is the joy of Christ'. The second interpretation would go beyond devotion to Christ to an actual sharing of Christ's experience (Panikkar 1998:19), which does more justice to Abhishiktananda's emphasis on the importance of having the same experience as that of Christ. Christ's 'anointing' was his experience of Sonship with the Father. Abhishiktananda equated this experience of Sonship with the Hindu advaitic experience. In his view, this experience is the most important goal of human life. Abhishiktananda's entire life was a dialogue between his Western traditions and the Eastern Hindu traditions that he sought to understand and to experience.

\section{The nature of Abhishiktananda's advaitic experience}

Abhishiktananda understood his experience as advaitic but not monistic, whereas the Western interpretation of Advaita was often monistic. Abhishiktananda insisted that although the advaitic vision is that of 'not two' (non-dual), the advaitic experience is not that of 'only one' (monism). He insists that the experience is neither dvaita [two] nor eka [one] but a-dvaita [non-dual] and an-eka [not one], which gives value both to unity and diversity simultaneously. Individuality is not swallowed up or identified with the One. He speaks of Advaita-aneka [not two, not one], '...God himself ${ }^{5}$ is both one and many in his mystery - or rather, to put it more accurately, he is not-one, an-eka, and also nottwo, a-dvaita' (Abhishiktananda 1984:135). The distinction between Advaita and monism is crucial for understanding the vision of Abhishiktananda. It plays an important role in his attempt to reconcile Hindu and Christian thought. Abhishiktananda's use of the term an-eka is also central to the understanding of his vision. Monism has a tendency to deny and to devalue the world, which would lead to an 'acosmism' in actions. Only if the world of diversity has reality, is there a basis for a more dynamic interaction with the world. A monistic understanding of reality, that insists there is nothing but Brahman, will see the world of diversity as maya [unreal or illusion]. A non-monistic understanding of Advaita can revise this view of maya, granting reality to diversity as well as to unity. Abhishiktananda achieved this through incorporating the Saivist ${ }^{6}$ concept of sakti [power] into his system of thought. He tried to give a more positive view of maya by looking at it in terms of the sakti, or energy of God. This would amount to a revision of the classical Hindu concepts of maya and sakti.

Abhishiktananda tried to describe his experience using Western language, as well as by using and interpreting Hindu ideas. He emphasised the priority of experience (anubhava) over concepts. He believed that all genuine religious documents and scriptures have their origin in the immediate personal experience of 'seers' or rishis. Abhishiktananda wanted to reinterpret Christianity on the solid foundation of advaitic philosophy, just as the Fathers of the Church interpreted Christianity on the basis of Greek philosophy. According to Abhishiktananda, the advaitic experience of Jesus is equally available to every human being. He believed that the early Upanishads report a similar experience to that of Jesus, as expressed in Jesus' declaration that he and the Father are one (Jn 10:30; Wiseman 2006:169). As per the nonmonistic Advaita proposed by Abhishiktananda, the world is not an illusion. According to him, the monistic interpretation of Advaita developed only at a later stage as a result of the 'dialectics' of the disciples of Sankara. Following the teachings of his mentor and his inspiration, Gnanananda Giri, and also Ramana Maharshi, he made a distinction between a pure consciousness experience (nirvikalpa or kevala samadhi) and a return to the world of diversity in sahaja samadhi. Sahaja samadhi is the state of the jivanmukta - the one who is liberated whilst still in the body. Abhishiktananda believed that he experienced sahaja samadhi and not nirvikalpa samadhi, which was the ideal suggested by Ramana Maharshi, whom he tried to follow. Abhishiktananda used non-monistic Advaita to reinterpret classical Christian ideas such as that of Creation and of the Trinity. Kalliath (1996) defended the position taken by Abhishiktananda regarding Advaita by stating:

Advaita is often misinterpreted or mistaken as monism because everyone tries to understand it exclusively through the Advaita-vada of Sankara, which is prominently monistic in nature. Abhishiktananda understands Advaita directly from the Upanishads along with his Christian background without leaning on any Vedantic school.

(Kalliath 1996:369)

However, Ramana Maharshi, the inspiration behind Abhishiktananda, comes to the defence of Sankara, saying:

Sankara has been criticized for his philosophy of maya (illusion) without understanding his meaning. He made three statements: that Brahman is real, that the universe is unreal, and that

6.The divine couple Siva-Sakti corresponds to two essential aspects of the One. Siva, the masculine principle, represents the constitutive elements of the universe, while Sakti, the feminine principle, is the energy within or the inherent dynamic potency. Sakti, the feminine principle, is the energy within or the inherent dynamic potency.
The whole universe is perceived as being created, penetrated and sustained by these two fundamental forces. 
Brahman is the universe. He did not stop with the second. The third statement explains the first two; it signifies that when the Universe is perceived apart from Brahman, that perception is false and illusory. What it amounts to is that phenomena are real when experienced as the Self and illusory when seen apart from the self.

(Maharshi, cited in Osborne 1978:16)

Abhishiktananda was absolutely convinced that the advaitic experience is ineffable and he often speaks of this difficulty of expressing the ineffable. For him, any description of the ineffable is in the realm of namarupa [names and forms]. Going 'beyond' concepts, myths and archetypes was, for him, the same as a return to the original intuition of 'Immediate Experience'. Abhishiktananda emphasised that Advaita should not be seen as an idea, for advaitic experience goes beyond all ideas:

Advaita is not an idea. It is! The lightning flashes, the eye blinks, as says the Kena [Upanishad]. Then? You have either understood, or you have not understood ... If you have not understood, too bad! says the same Upanishad. If you have understood, you keep quiet, says the Mundaka [Upanishad].

(Abhishiktananda, cited in Stuart [1989] 1995:227)

Sometimes Abhishiktananda follows this advice, and says that the advaitic experience is impossible to describe and that it can only be indicated by silence: 'There is no thought about the mystery which is not already namarupa. The experience at the original moment cannot be discerned except in an "Ah"! (Kena Upanishad 4,4)' (Panikkar 1998:370). Abhishiktananda's emphasis on the value of silence is paramount: it is from 'eternal India' that the West can learn the value of the apophatic way, the way of emptiness and quietude (Abhishiktananda 1983:41). Although silence was of prime importance in the thought and life of Abhishiktananda, he nevertheless continued to value and promote liturgical prayer. However, he maintained that it needs to be rooted in contemplative experience (Wiseman 2006:170).

At times, Abhishiktananda writes of the difficulty of expressing the advaitic experience, except in cultural terms:

Of course I can stammer a few words. But that will never be more than some concepts, strictly dependent on my cultural, social, religious and mental environment, on all the previous development of my thought and my consciousness.

(Abhishiktananda, cited in Panikkar 1998:371)7

In spite of his insistence on the ineffability of his experiences, Abhishiktananda was a prolific writer who enthusiastically attempted to conceptualise and communicate his experiences. From his personal diaries and letters in particular, it is evident that he did not achieve the advaitic experience until at least 1972, the year before he died, and perhaps not even until his heart attack in 1973. In 1953, whilst in the Arutpal Tirtham cave at Arunachala, he wrote that he had had more the idea of Advaita than the res [the thing itself, the reality]. He wrote that he had not had the experience itself:

7.See Katz (1978, 1983, 1992) for an analysis of the constructivist position. Abhishiktanda's statement would seem to lend weight to Katz's argument. However, with respect to Abhishiktananda's general mystical philosophy, it would be more accurate to locate his general approach within an essentialist rather than a constructivist position. Also see Karuvelil (2010) for an interesting critique of Katz' views.
For the time being I am playing with Advaita. I am like someone on the point of taking a swim in the sea, who reassures himself, dips a toe in the water, and indefinitely postpones the dive which alone will give peace. I try to understand my Advaita as a Christian and a Westerner ...

(Abishiktananda, cited in Panikkar 1998:66)

In 1967, Abhishiktananda expressed the fear that, despite all that he had written, his so-called experience might be nothing but a projection of his desire to exist (besoin d'être) (Panikkar 1998:294). In May 1972, Abhishiktananda was in an ashram near Rishikesh with his disciple, Marc Chaduc. Whilst there, Chaduc had a profound spiritual experience and it was only at this time that Abhishiktananda's doubts were dispelled. He wrote in his diary, 'The experience of the Upanishads is true, I know it!' (Panikkar 1998:348). On 23 July 1973 he wrote to Odette Baumer-Despeigne that he had experienced the Awakening:

It is wonderful to undergo such an experience which brings the fullness of peace and joy beyond all circumstances, even those of death or life. Life can never be the same since I have found the Awakening! Rejoice with me.

(Abhishiktananda, cited in Baumer-Despeigne 1993:24)

Abhishiktananda described going beyond all notions as the 'explosion' of our concepts:

Again, if my message could really pass, it would be free from any 'notion' except just by the way of 'excipient'. The Christ I might present will be simply the I AM of my (every) deep heart, who can show himself in the dancing Shiva or the amorous Krishna. And the kingdom is precisely this discovery ... of the 'inside' of the Grail! ... The awakening is a total explosion. No Church will recognize its Christ or itself afterwards. And precisely for that (reason), no one likes the 'atomic mushroom'!

(Abhishiktananda, cited in Stuart [1989] 1995:311)

Finally, he also wrote the following to his sister:

It was a marvellous spiritual experience. The discovery that the AWAKENING has nothing to do with any situation, even socalled life or so-called death; one is awake and that is all. While I was waiting on my sidewalk, on the frontier of the two worlds, I was magnificently calm, for I AM, no matter in what world! I have found the GRAIL! And this extra lease of life - for such it is - can only be used for living and sharing this discovery.

(Abhishiktananda, cited in Stuart [1989] 1995:308)

\section{Abhishiktananda's non-dual perception and 'beyond'}

Abhishiktananda held the view that the world is not totally unreal. The world is anirvacaniya or indescribable and indeterminable as either real or unreal. We are actually experiencing the Reality; yet, we do not recognise it. As a result of our ignorance, we are unable to see Brahman in the universe. Taking the pluralistic universe of material objects as real is maya, which is like seeing a rope as a snake. Once the true identity of the 'snake' is revealed, one would say that one had been seeing a rope. At all times our actual perception (experience) is of Brahman, even though we are often ignorant of it and incorrectly identify 
it. There are two possibilities: a false perception and a true non-dual perception. The ignorant do not see Brahman in the universe because of superimposition or savikalpa thought construction. When these superimposed concepts are removed, Brahman, or the Reality, is experienced as it is. Our thought constructions prevent us from seeing the 'true' non-dual nature of reality. Abhishiktananda therefore believed that there must be a recovery of the world after the emptiness of Pure Consciousness. There is a return, an 'awakening' from the awakening. Abhishiktananda sometimes expresses the opinion that this further awakening is not found within Hinduism, but only in the biblical tradition. He says that Indian seers say that those who experience the ultimate experience pass beyond their selves and do not recover their selves. According to this view, the seer never recovers the external and mundane self. But Abhishiktananda says that the biblical view is that Moses came down from the mountain; Paul returned from the third heaven (Abhishiktananda 1984:6). Abhishiktananda insists that beyond Advaita there is a further experience, which he called ati-Advaita, or Advaitatita. In this state, one experiences the mystery of the Three in One and the One in Three (Unity and Trinity). This is a trans-advaitin mystery of the Father, Son, and Spirit, the mystery of God in Godself, of the Self of God and of Being which is supra-personal and tri-personal. But Abhishiktananda also says that to speak of any numbers such as 'three' or 'one' is not possible when we go beyond Advaita. The sages of India were correct to say neither one nor many, but just to say, not-two, Advaita, and not-one, aneka.

Abhishiktananda says that beyond Advaita, the mystery of the Trinity is revealed. The world of distinction, the an-eka begins to emerge again (ressurgir) from the Sunyata [emptiness] into which everything seemed to have disappeared. In the kevala [absolute state], one goes beyond space and time and even beyond eternity and Being, and beyond God as conceived, in order to appear again as from the primordial yoni [womb]. This reappearance is the resurrection; one passes from the 'Eternal-Being-consciousness' back again to the world of maya, the 'Temporal-non-Being-consciousness' (from kevala back to namarupa). It is passing from God as 'the One', who is without any second, to God as Creator and to God as Love and kenosis. For the Love of God is the same as the kenosis of God.

These ideas are important in explaining Abhishiktananda's 'non-monistic Advaita'. The trinitarian awakening breaks through the dilemma of either dualism or monism. There is a rejection of the duality that imagines we are other than the rest of the world. There is a return to the world in an experience of communion and unity. The advaitic experience shows the falsity of dualism. This 'advaitic slumber' is 'a necessary precondition' of our awakening. Abhishiktananda holds the view that we should not stop at the monism of the Pure Consciousness experience - an 'awakening' from the awakening has to follow. This new awareness is the fact that 'being is essentially "being-with", communion, koinonia, the free gift of the self and the mutual communication of love' (Abhishiktananda 1984:176). These ideas of communion are also related to Abhishiktananda's trinitarian view of Being.
Abhishiktananda says that the Christian who awakes after the advaitic night once more finds himself or herself, as well as the world, but now at a deeper level. There is a 'recovering' of self and the world, and of the reality of time, of becoming, of particularity and multiplicity. At this stage, one realises that the world is full of value and significance, even at the level of its temporality and diversity:

God - eternal, absolutely self-existent, with all his infinite love, his creative power and his inner tri-personal life - is fully present in the tiniest speck of matter or moment of time, in the grain of sand, in the smallest microbe, in the most trivial event in the world or the life of the individual ... No one has the right to say that God is there only in a diminished or downgraded manifestation of himself, from which the sage must turn away, either by thought or by will or by 'isolation' or contemplation, in order to attain to the Real. No, the Real is precisely there.

(Abhishiktananda 1984:128, 129)

This is a clear statement of Abhishiktananda's view of a nondual perception of the world, seeing Brahman everywhere and within all things. The jnani [enlightened one] does not discover anything new as a result of this enlightenment. The jnani just sees reality in all its glory and penetrates to the essence of things and there discovers Yahweh-Brahman, 'the One who IS' (Panikkar 1998:288). Abhishiktananda was fully aware that his ideas of a further awakening and communion reflect Christian ideas. He tried to discover in the Christian Advaita something beyond Vedantin Advaita.

\section{Seeing Brahman in all things}

According to Abhishiktananda, everything is a manifestation of God, but in its own unique way: when once we reach the heart of a sign, we realise that everything is essentially an epiphany, a manifestation of the Lord. Thereafter, what is important are not the differences and disparities between the manifold manifestations, but the quality common to all of them - and to each of them in a unique manner - of being a sign of God. This extends from oneself to every conscious being that has ever existed or will exist, from the atom or the smallest living creature to the galaxies. Now the heart has been discovered in everything - the heart in which all is discovered, all is seen, all is known. Nowhere is there anything but God in Godself. Only then can the taste of Being be appreciated. Thereafter that taste - that, and no other - is recognised in every being (Abhishiktananda 1990:42, 43):

In this ... experience one is no longer able to project in front of oneself anything whatsoever, to recognise any other 'pole' to which to refer oneself and to give the name of God.

(Abhishiktananda 1974:151)

Abhishiktananda does not deny that there are distinctions and unique manifestations of Being. What is important is 'the common quality' to them all, namely, that they all have the same 'taste' of Being. It is more important to recognise that God is present in all things than to try to understand how this is so. This is why the anjali [folded hands] greeting can be made, acknowledging God in other people (Panikkar 1998:38). Whilst Abhishiktananda was meditating in the caves of Arunachala, he was disturbed by noise from loudspeakers that were set up in the town below. In his diary he writes that 
even that noise may be perceived as God (Panikkar 1998:45). He considered seeing God in other people or creatures the same as prayer. For Abhishiktananda, to see all things with eyes enlightened by faith - all things created by the Father to help humanity in its ascent towards him - is also nothing less than prayer and contemplation. The presence of God in everything leads us to God. But the presence of God is also seen after the awakening:

The presence of God will therefore be the first thing which the jnani will see in everything he sees or meets with. It is the first thing also which the ordinary man sees in the saint whose darshana he has the grace to obtain.

(Abhishiktandana 1969:167)

Non-dual perception is 'going beyond' the distinction of self and non-self. It is not a denial of such a distinction. Abhishiktananda continued to regard distinctions as real. In experience, the duality of object and subject is transcended. To transcend the distinction does not necessarily mean to deny that it exists. The advaitic experience is not replacing one concept with another. 'It is not a question of trying to persuade oneself that no differences exist' (Abhishiktananda 1990:80). That would be to deny our experience in the name of logic. Abhishiktananda criticised the followers of Sankara who, by their rigid application of concepts, deny the reality of the world. He also extends the same criticism to Nagarjuna's dialectic, which denies subject as well as object.

\section{Three abysses of God} The divine mysteries

Abhishiktananda says that there are three divine abysses or mysteries that we successively discover in God. They are, (1) the Mystery of Unity or Advaita, (attained through neti neti or apophaticism), (2) the Mystery of Trinity or of an-eka [not-one or many] and (3) the Mystery of Charity or of the kenosis [selfgiving or self-emptying].

Abhishiktananda asserts that God and creation co-exist and the basis of this co-existence is a 'mystery'. Despite this coexistence, one can also say that there is no second to God (ekam eva advitiyam) because of the totally dependent nature of the existence of creation. Abhishiktananda frequently uses the idea of 'mystery' to justify holding to both the view that only Brahman is Real, and the view that the world is real. 'Mystery' is an experience beyond what can be spoken, imagined or conceived. The mystery is that there is both non-duality and difference, 'The individual is the mystery of God realized in a not-one (aneka) way in its ... indivisibility as undivided nonduality (akhanda-Advaita)' (Panikkar 1998:214). According to Abhishiktananda, the two aspects of the divine mystery unity and multiplicity (Advaita and aneka) - are inseparable. Both ideas must be maintained in full force and one should not be diminished in order to exalt the other. The Mystery of kenosis is that of the eternal emergence of being from the primordial non-manifested. God has chosen to have creation, not to be without it. Creation is the kenosis of God, the selfemptying in love, the issuing from the One. Abhishiktananda says that this kenosis entails a real death of God. There is a movement from God as One without a Second to God as Creator and God as Love, which is a kenotic process. God no longer has the attributes of kevala [absolute], ekatva [oneness] or Advaita [non-duality]. Abhishiktananda wonders whether we can still say that God exists after this kenosis. The kenosis is a giving of God's self. This is why no one has ever seen the Father, but only the Son. Now it is in and through creation that God manifests Godself. The world comes from God and it returns to God. Because of this dependence on God, maya is neither being nor non-being. The world is on its way towards God, like Christ, passing to the Father. There is no maya in the strict sense of the word, except for those who separate the universe from its ground and who separate the aspects of 'being' and 'becoming' in the divine nature.

\section{Trinity}

\section{A Christian solution to the Hindu riddle}

Abhishiktananda believed that the Trinity solves the problem of the One and the Many. In the perspective of the Trinity, the antinomy of the an-eka and the Advaita, the not-one and the not-two, which obsessed the Indian seers for millennia, could be understood. The doctrine of the Trinity helps us to avoid both dualism and monism. The Word is both with God as well as being Godself. If the Word is God, we cannot say two (in a numerical sense) of Word and the Father; there is no place left for any division or duality (Dvaita) of any kind. But if the Word is with God, then God is not a mere monad either. Similarly, the lack of distinction between Brahman and the world does not necessarily mean their identity. Abhishiktananda affirms:

Between God and the human person there is nothing that could be counted. I do not say that the human being is God or that God is the human being, but I deny that the human being plus God makes two.

(Abhishiktananda, cited in Panikkar 1998:151)

Abhishiktananda reiterates that this experience of both identity and diversity is ineffable (anirvachaniya) (Pannikkar 1998:375). It is not to be explained in terms of either unity or of difference. There is the non-unity of God and the human being. There is their non-duality - and there is what is at the same time beyond non-unity and beyond non-duality (Panikkar 1998:101). He says that this mystery of the Trinity is something that India and even its most preeminent yogis could not discover. According to him, the Trinitarian experience goes beyond and transcends the experience of Hindu jnanis. Abhishiktananda acknowledges that the otherness of God is not just a result of projection. Jesus' statement 'the Father and I are one', should be regarded at the same time as in Dvaita and in Advaita (Panikkar 1998:32).

\section{The contribution of Abhishiktananda to Trinitarian thought ${ }^{8}$}

Abhishiktananda's non-monistic Advaita affirms the reality of both unity and diversity in the world. He challenged monism that questioned the reality of the world and insisted on an-eka. Abhishiktananda was also in conflict with dualism that upheld the existence of a world opposite to God; hence, he

8.John Glenn Friesen has done an excellent study on Abhishiktananda's non-monistic advaitic experience for his Doctorate in Literature and Philosophy at the University of South Africa (2001). The full text (three vols.) is available on the Internet (see of South Africa (2001). The full text (three vols.) is available on the Internet (see
reference list for details) and we are indebted to it for many of the ideas found in this article. 
endorsed Advaita. The Christian understanding of the Trinity inspired Abhishiktananda's non-monistic understanding of Advaita. It encouraged him to affirm unity in diversity, or transcendence in immanence. However, his interpretation of the Trinity was unorthodox. According to him, the Father, who is ekam advitiyam, One-without-a-Second, gives himself in love in the process of kenosis in manifesting the world or Son. This process is the evolution from the One. The Spirit is the unity between Father and Son and brings us back into unity in the process of involution until God is again all in all. Abhishiktananda calls this the Pleroma.

Abhishiktananda believed that the Trinitarian experience is present even within Hinduism. He argues that a non-monistic interpretation of the Upanishads can uphold both a static and dynamic conception of Brahman (as emanating the world) and the idea of sakti, which expresses the dynamic power of Shiva in the creation of the world. Abhishiktananda argued that it is the over rationalisation of Upanishadic teaching by Sankara that leads to the degradation of the world as maya. He taught that in the advaitic experience of kevala, or nirvikalpa samadhi, Brahman is experienced as Advaita beyond all dualities, space and time, and distinction between subject and object. A person having this experience will no longer fear death because he or she knows the eternal nature of the true Self. If a person survives the kevala experience, he or she returns to the world of diversity; this is the sahaja experience of jivanmuktas. The advaitic experience is an experience of wholeness rather than just a part of our being. Abhishiktananda held the view that it can be experienced, though such experience cannot be described in conceptual terms.

Although Abhishiktananda was very much influenced by the Upanishads, he utilised other systems of thought, including Buddhism and Kashmir Saivism', to facilitate his search for reality. Abhishiktananda understood the kevala experience in terms of the Christian concept of purification taking place in the Dark Night of the Soul often described by the Western mystics. He interpreted the sahaja stage as the resurrection from this 'death'. This is a distinctly Christian interpretation of sahaja which is not acceptable to most Hindu authorities who consider prarabdha karma ${ }^{10}$ as the true cause for the continuation of a jivanmukta in a physical body. Abhishiktananda considers the advaitic experience as an experience of Being 'I am who I am' revealed by Yahweh in the Bible. He says that in our own advaitic experience we are also invited to have the same experience of Jesus, who recognised his non-dual relation with God his Father. It is not evident from the writings of Abhishiktananda whether he ever experienced the kevala experience in the sense that he described it. It was his disciple Chaduc who had such an

9.Kashmir Saivism or Trika philosophy is a world-affirming vision which holds the view that the universe is nothing but the blissful energy of an all pervading consciousness - Siva. This consciousness has three levels of existence - para, parapara and apara. The Trika system teaches one to rise from objective energy through cognitive energy and finally reach the subjective energy of Siva, the divine consciousness. According to Kashmir Saivism matter is not separate from or opposed to consciousness, but to Kasher identical, yet a dense and dark form of it. There is no gap between God and rather identical, yet a dense and dark form of it. There is no gap between God and is illusion.

10.Karma is of three kinds: Sanchita (accumulated works), Prarabdha (fructifying works) and Kriyamana or Agami (current works). Prarabdha Karma is that portion of the past Sanchita Karma (merits/demerits) which is responsible for the present body. experience and Abhishiktananda may simply have had a vicarious experience of it. His own experience did not occur until his near-death episode, resulting from his heart attack in 1973. This does not appear to have been an experience of kevala in the sense of Pure Consciousness., but that does not mean that Abhishiktananda did not achieve an advaitic experience in the sense of sahaja.

\section{The challenge for Christianity}

Abhishiktananda's life and teachings offer a real challenge to traditional Christianity. He tried to reinterpret almost every Christian doctrine: the nature of Christ, the uniqueness of Christ, sin, salvation, divinity, resurrection, and even whether a belief in theism could be justified. He relativised all doctrines in favour of immediate experience. Abhishiktananda regarded Sacred Scripture as a record of the human experience of the divine. According to him, the problem with the Christian Church is that it tries to objectify and to essentialise salvation, whereas salvation is, in fact, an existential decision (Panikkar 1998:273). However, this position challenges the reason for the existence of the Church itself. If salvation is purely an existential decision, then the necessity of the Church as an institution is reduced to the preserver of myths and dogmas. Abhishiktananda insists that the revolution brought by Jesus was defused from the very first Christian generation and lost its mystery and its power when it became a religion (Panikar 1998:307, 367). It formulated clever doctrines in order to shield people from the force of the immediate experience. He considered the formulas of the Church councils as an attempt to absolutise that which cannot be defined.

Abhishiktananda's way of life and his articulation of Christianity within the contours of advaitic thought can be seen as an example of lived interspirituality. Of course, such an experiment raises questions as to the viability of crossing boundaries between diverse religious traditions. Many scholars engaged in inter-faith dialogue are uncomfortable with such an endeavour and critique its basic assumptions, which are felt to be too liberal. Instead of accepting interspirituality at an experiential level, such scholars prefer to concentrate on the debate concerning differences, propositions, sociological and cultural variants with respect to different faith positions. Furthermore, many Christians, both scholars and others, are disturbed by the possibility that different religious traditions may offer universally relevant teaching. However, Knitter (1996:168-183) for example, maintains that such a liberating approach can actually facilitate Christian growth:

To know the God of Jesus is to have the security and the courage to follow the Spirit wherever she might lead - even when she leads us to truth other than what we have found in Jesus.

(Knitter 1996:174)

Therefore, whilst respective epistemological foundations may differ, mutual understanding and respectful dialogue will facilitate respect for the autonomy of diverse traditions and enhance mutual enrichment. As a result of the interspiritual encounter that is a feature of contemporary spirituality, and which found profound expression in the 
life and thought of Abhishiktananda, there is a shift from divergence to convergence. Consequently, attitudes of domination, triumphalism and colonialism with respect to the other can be replaced with reciprocal understanding, mutual respect and constructive dialogue. This is not to deny the fact that differences relating to particular theological, cultural, religious and sociological parameters affect not only cognitive articulation of the tradition, but also the very experiences undergone by the adherents. Each is something suigeneris - and this particularity is not to be underestimated. It is recognised that there are multiple dimensions and expressions of the sacred. Nevertheless, interspiritual exchange, such as that practised by Abhishiktananda can help promote respect and greater understanding of the particularities of diverse traditions.

\section{Conclusion}

As we have seen, Abhishiktananda's search for truth and experience forced him to borrow heavily from all the sources available to him, so much so, that it is difficult to confine his thoughts into any one religion. He relativises all religions, just as he relativises all concepts. He considered all doctrines as products of conceptualisation in the realm of namarupa. Yet, he acknowledged the necessity of myths, religions, rites and rituals, as well as concepts for the purpose of sharing our experiences. Abhishiktananda was a monk, mystic and bridge builder. He made an important observation that although 'Advaita' means 'not-two', it does not mean 'only one.' In other words, Advaita is not monism. This allows for a distinction between God and created reality whilst still affirming their unity. He knew that, doctrinally, Advaita and Christianity contradict each other and there is no way to combine or resolve these doctrinal expressions. However, he believed that the experience of Advaita transcends conceptual expression. Therefore Abhishiktananda made himself a laboratory of spiritual alchemy to prove that Advaita is not in conflict with Christian doctrine. He became a voice crying in the desert of humanity's mediocrity, blind rigidity and fanaticism. Abhishiktananda's greatness lies in having lived, within himself, the symbiosis of two traditions, the Hindu and the Christian, in such a real way that both became part of himself, without his ever being able to reject or disown either.

It is no secret that Christian missionaries were often accused of being agents of destruction of indigenous cultures and of playing an auxiliary role in the spread of European imperialism. However, the creative role they played in nurturing a deeper understanding of the religious heritage of the East should not go unnoticed. It is thanks to their close encounter with the Asian religions that the European ignorance about Asian religions was dispelled. Some missionaries even dared to become advocates and promoters of Asian religious and philosophical traditions against the European values and assumptions and opened a pathway to dialogue. In this respect, Abhishiktananda played a unique role by giving primacy to his own mystical realisation over the theological doctrines to which he was formally committed as a Christian. Abhishiktananda, through the penetration of religious forms, became a true sanyasi which is to say, he crossed the boundaries of religion. He wrote in The further shore, 'The call to complete renunciation cuts across all dharmas and disregards all frontiers ... it is anterior to every religious formulation' (Abhishiktananda 1975:27). Abhishiktananda never denied or repudiated the doctrines or practices of either Christianity or Hinduism, nor did he cease to observe the Christian forms of worship and to celebrate the sacraments; rather, he came to understand their limitations as religious forms. He regarded religious structures (doctrines, rituals, laws, techniques, etc.) as signposts to the Absolute, but they could not be invested with any absolute value themselves (Abhishiktananda 1979:47). Through his writings, we can observe a move away from all notions of Christian exclusivism and triumphalism, towards the eternal wisdom.

\section{Acknowledgements Competing interests}

The authors declare that they have no financial or personal relationship(s) which may have inappropriately influenced them in writing this article.

\section{Authors' contributions}

The authors of this article made equal contributions with regard to the research and writing of the content herein.

\section{References}

Abhishiktananda, 1969, 'An approach to Hindu spirituality', Clergy Review 54(3) 163-174.

Abhishiktananda, 1974, 'Experience of God in Eastern religions', Cistercian Studies 9, 151-152.

Abhishiktananda, 1975, The further shore, Indian Society for Promoting Christian Knowledge, New Delhi.

Abhishiktananda, 1979, The secret of Arunachala, Indian Society for Promoting Christian Knowledge, New Delhi.

Abhishiktananda, 1983, The eyes of light, Dimension Books, Denville, NJ.

Abhishiktananda, 1984, Saccidananda: A Christian approach to advaitic experience, Indian Society for Promoting Christian Knowledge, New Delhi.

Abhishiktananda, 1990, Guru and disciple, Indian Society for Promoting Christian Knowledge, Delhi.

Baeumer, B., 2000, Abhishiktananda and the challenge of Hindu-Christian experience, Bulletin 64, viewed 15 October 2010, from http://www.monasticdialog.com/a. php?id=305

Baumer-Despeigne, O., 1993, 'The spiritual way of Henri Le Saux Swami Abhishiktananda', Bulletin of Monastic Interreligious Dialogue 48, 20-25.

Friesen, J.G., 1998, 'Abhishiktananda: Hindu advaitic experience and Christian beliefs', Hindu Christian Studies Bulletin 11, 31-38.

Friesen, J.G., 2001, 'Abhishiktananda's non-monistic advaitic experience', unpublished D. Litt et Phil. thesis, Department of Religious Studies, University of South Africa, viewed 15 October 2010, from http://members.shaw.ca/abhishiktananda/Abhi. thesis.pdf

Kalliath, A., 1996, The word in the cave: The experiential journey of Swam Abhishiktananda to the point of Hindu-Christian meeting, Intercultural Publications, New Delhi.

Karuvelil, G., 2010, 'Mysticism, language and truth', Journal of Dharma 35(3), 259-275. Katz, S. (ed.), 1978, Mysticism and philosophical analysis, Sheldon Press, London.

Katz, S. (ed.), 1983, Mysticism and religious traditions, Oxford University Press, Oxford. Katz, S. (ed.), 1992, Mysticism and language, Oxford University Press, Oxford.

Knitter, P., 1996, 'New possibilities for interreligious dialogue', in B. Bruteau (ed.), The other half of my soul: Bede Griffiths and the Hindu-Christian dialogue, pp. 168-183, Quest Books, Wheaton, IL.

Osborne, A., 1978, The teachings of Ramana Maharshi, Samuel Weiser, New York, NY. Panikkar, R. (ed.), 1998, Ascent to the depth of the heart: The spiritual diary (1948-73) of Swami Abhishiktananda (Dom Henri Le Saux), OEIL, Paris.

Stuart, J. (ed.) [1989] 1995, Swami Abhishiktananda: His life told through his letters, Indian Society for Promoting Christian Knowledge, New Delhi. Wiseman, J.A., 2006, Spirituality and mysticism: A global view, Orbis Books, New York, 